\title{
THE SURVEY OF CHRISTIAN LITERATURE IN CHINA
}

\author{
By The Rev. GEORGE A. CLAYTON
}

The first attempt to prepare a catalogue of the publications in Chinese of the Protestant churches in China was made by Alexander Wylie, who came to China in 1847 to superintend the press established by the London Missionary Society and was transferred to the service of the British and Foreign Bible Society in 1863. The purpose of his book is amply described by its title, Memorials of Protestant Missionaries to the Chinese: giving a list of their Publications. The method followed is to give a brief sketch of the work of each missionary from Marshman and Morrison to the latest arrival in 1866, whether such missionary had engaged in literary work or not. In the case of those who had already produced literature in Chinese, or dealing with matters Chinese, as full details as possible about each publication are given, most entries including a careful analysis of the contents. A few publications by Chinese authors are also included. No less than 765 titles are indexed, the greater part being tracts such as are needed when entering new fields in order to place the salient doctrines of Christianity clearly before the prejudiced literati. But these early missionaries had not forgotten the needs of the Christian community and of the scholars in the schools which had been founded. There were twenty-two volumes of comment or notes on books of the Bible, several volumes of sermons, no less than thirty-four catechisms, and a few books on history, geography, astronomy, mathematics and medicine.

In 1876 the Chinese Maritime Customs asked Mr Wylie 
to undertake the revision of his former work as far as the list of publications was concerned. This revised list, which included 1036 titles, was issued as an appendix to the Chinese Maritime Customs Report on the Philadelphia Exhibition, 1876. It is understood that an exhibit of the books and tracts was sent to Philadelphia.

The outcome of this action of the Chinese Customs was a decision at the Shanghai Missionary Conference of $\mathbf{1 8 7 7}$ to publish a catalogue of Christian literature in Chinese and to keep the missionary body informed about new publications. Up to 1882 this decision seems to have had no fruition, for when Dr Murdoch paid his memorable visit to China the committee which he called together reported that 'it was generally acknowledged that a great part of the existing Protestant literature in Chinese was unknown to many missionaries' and resolved 'to collect information about books and tracts already published: to form a complete library : to prepare a classified catalogue ... and to revise the catalogue from time to time.' This task was delegated to a committee of seven, but was accomplished by the Rev. Dr MacGillivray on his own initiative in 1907. His list was completed in manuscript by the author while journeying, but ere he reached Shanghai the native craft in which he was travelling was capsized and everything which he had with him was lost. With characteristic perseverance Dr MacGillivray prepared a fresh manuscript, and this was issued for the Centenary Missionary Conference in 1907. It was recognized as invaluable.

Such lists as those just mentioned need constant revision, but the burden of work which rested, and rests, on Dr MacGillivray made it impossible for him to undertake such a task. None of the publishing houses undertook it and the Centenary Conference did not appoint any permanent committee charged with this responsibility. But when Dr Mott held his conferences in Asia in 1912-8, both at sectional and national conferences in China there was an insistent demand by the missionary body for the 
revision of Dr MacGillivray's list and for some system under which the needs of the Chinese churches for various kinds of literature could be voiced. The formation of the China Continuation Committee provided the permanent body to whom this task could be entrusted, the publication of $\mathrm{Dr}$ Ritson's masterly report on Christian Literature in the Mission Field suggested the lines which should be followed, and the creation of the Christian Publishers' Association of China facilitated the preparation and publication of such index to existing Chinese Christian literature as the China Continuation Committee might decide to publish.

The Index ${ }^{1}$ which was published in April, 1918, differed from its predecessors in one important respect. They were issued in English with the title of the publications in both Chinese and English; this is issued in two forms, the one giving all the information about the books and tracts in English, the other giving exactly the same information in Chinese. The provision thus made that the persons who ought to be the users of this literature can secure information firsthand, and not only through the missionary, ought to characterize all future indices.

The first thing which strikes the user of the Index is the fact that there already exists in Chinese a very valuable library of books issued under Christian auspices. The total number of entries in the Index is 3451, and this total does not include the publications of the Roman Catholic and the Greek churches. Treating a publication of fifty or more pages as a book, one finds that the grand total can be divided into 1188 books, 1152 booklets, 1066 folded and sheet tracts, while the balance consists of charts and maps. The value of the tract as an evangelistic agency is beyond question, but limitations of space render it impossible in this article to show how splendidly the missionary body has faced this need and how largely the need has been met. New tracts on passing phases of thought will ever be

${ }^{2}$ A Classified Index to the Chinese Lilerature of the Protestant Churches in China. By G. A. Clayton. Hankow: Chinese Christian Publishers' Association. 
welcome, but among the very oldest of the tracts and booklets are many which still rightly enjoy an immense circulation, for they contain a positive statement of the great truths which, though old, are ever new. Milne's Troo Friends, Genahr's Conversations with a Temple Keeper, John's Gate of Virtue, Li Wei-yu's Avoid the Wrong, Judd's Exhortation to the World and other such masterly though brief presentations of the Christian view will maintain their circulation so long as superstition raises its head.

Limiting one's attention to the books and booklets included in the Index, one finds that the great majority must be classified under the main heading, 'Religion.' This is, of course, what one would expect. The primary purpose of the missionary in coming to China is to publish the good news of salvation, and naturally the bulk of the literature which he produces will find its theme within the pages of Holy Writ, or aim to cast light from other sources on the relations of God to man. And at the present day, when the Commercial Press and other Chinese publishing houses are working in a thorough and satisfactory way to meet the need of the Chinese people for general literature and for school books, the natural tendency will be for the Christian writers to give more and more of their time and strength to the production of that distinctly Christian literature which Chinese publishers do not as yet attempt to provide. As one might expect, there will be unfortunate mistakes made by these Chinese publishers, but it is satisfactory to know that at present the heads of the two largest houses are Chinese Christians and that the heads of the Commercial Press in particular have undertaken not to issue any book which is unfairly hostile to the Christian position. In their great Dictionary they have, to quote an instance of the mistakes which may be made, included an explanation of the name 'Jesus' which does not mention the Divinity of our Lord and an explanation of the term 'Lord's Supper' which takes the Roman 


\section{$370 \quad$ International Review of Missions}

Catholic view. But on these matters being brought to their attention, expressions of regret were sincerely offered.

It may be of interest to mention the proportions in which the books and booklets fall under the ten main heads of the Index. Under Chinese Classics and reference books there are 12 entries ; under philosophy, 54; under religion, 1524; under sociology, 149; under political science, 35; under science, 109 ; under medicine, 103 ; under fine arts, 36 ; under literature, 149 ; and under history and geography, 168. Such questions as the relation of the teaching of the Chinese Classics to the teaching of Scripture, the bearing of Christianity on Chinese ethical standards, on home ideals, marriage and other customs and on jurisprudence, and the manifestation of the hand of God in history, will naturally engage the attention of Christian authors, but for the most part in the future as in the past, these authors will make the presentation of the message of salvation and the exposition of the Word the central and chief part of their message to the Chinese race.

When one analyses the books and booklets which fall under the general theme of religion, one is struck first with the paucity of works dealing with natural theology and the comparative study of religion. McCosh on Divine Government and Grant on Comparative Religions have been translated, but this section of the field is largely unoccupied. There is only one exposition of the doctrine of Confucius and that by a foreign missionary, though there are two or three attempts to comment on the Classics. Booklets which directly face the Buddhist and Taoist positions are few in number, while the literature which aims to meet the Moslem error can only be described as utterly inadequate. The recent formation of a strong committee to deal with this latter matter is a very hopeful sign, but before it can commence its work it will have to gather the terms used by the Chinese Moslems in their sacred books and discover the lines along which these followers of the Prophet can be best approached. 
Biblical introduction has been dealt with by several writers, the Bible Helps issued by the Oxford University Press being among the books translated. One concordance to the whole Bible has been issued, and another which is based on the Revised Chinese Bible is nearly completed. There is no satisfactory Bible history, and there is room for more work on Bible geography, though Smith's Historical Geography has been translated. As regards commentaries there is no lack, if one considers both those which are indexed and those which are known to be in preparation. The Annotated Paragraph Bible has been translated, and there is a series which covers all the books of the Bible based on the Cambridge Bible as far as it was issued up to 1913 and for the rest on the Pulpit Bible. Besides these two series there are commentaries, homiletical and expository, on most of the books by individual writers. There are for instance nine books dealing with Genesis in whole or in part, two on Exodus (with four other books on the commandments), four on Leviticus (with four on the great offerings), six on Matthew, six on Mark, and so on. Besides these the Christian Literature Society has projected a more advanced commentary on the whole Bible, while the Religious Tract Society is issuing in Chinese the well known Devotional Commentary. As regards dictionaries of the Bible, all reasonable needs have been, or soon will be, met. While one or two of the dictionaries now on sale are aut of date, the needs of students are met by the Chinese 'Hastings,' a work of approximately the same size as the one-volume 'Hastings,' and the needs of Sunday School teachers and lay preachers will be supplied when the Universal Bible Dictionary is issued. Besides these, a translation of the large dictionary edited by Professor Orr is well advanced, and this will serve for the students who are being trained on conservative lines.

Works on theology are undoubtedly inadequate in number and too largely written from the western standpoint. The advent of the Chinese theologian should be 
more than a matter of hope, it should be a subject for earnest prayer. Lives of Christ abound. Few of them are mere translations; most have been based on western originals, but these originals have guided, rather than fettered, the translators. Several of the translators have been Chinese, but no Chinese has as yet attempted to write a life of the Master. The time is perhaps drawing near when such an attempt will be made.

The number of volumes dealing with Christian evidences and with the apologetic statement of Christian truth is large. Many of these have enjoyed enormous circulations. Four publishers issue editions of Dr W. A. P. Martin's Christian Evidences, and it is impossible to find out exactly how many tens of thousands of copies have been sold. Dr Faber's great work on the fruits of Christianity as revealed in the progress of civilization has been equally popular. Our Chinese brethren have done more original writing in this section than in any other. Chinese names are largely unfamiliar in western lands, but here in China the writings of H. L. Zia, Y. K. Woo, Hang Hai, Pien Enchuan, Tong Tsing-en, Cheung Man-hoi, Wong De-gi, Li Wei-yu, Cheng Ching-yi, Chen Wei-ping, and Chan Mungnaam reach the hearts of their fellow-countrymen. Several of these writers have had the advantages which accrue from the knowledge of a western tongue, and therefore western originals sometimes underlie the books they produce, but even in these cases the western mould has been discarded and the thought transmuted into Chinese form.

The supply of devotional books is regular. Many of the most popular manuals in use in the West have been translated. Miss Havergal, Dr Torrey, Fosdick, Bound, Trumbull, Mott, S. D. Gordon, Eddy, Churchill King, J. R. Miller, F. B. Meyer, Josiah Copley, Campbell Morgan -though their western names may be unknown-are influencing the thought of the Christians of China. Of the unjustifiable multiplication of catechisms there is no need to write. About eighty are mentioned in the Index, and 
the compiler as the collection grew found himself wondering what justification could be offered for the publication of most of them. Of course there is no difficulty in securing a circulation for any catechism which is adopted by a whole mission or even by one healthy growing church. The unfortunate thing is that the supply seems constant. One tract society has declined two manuscripts since the Index was published, and one faces a strange problem in mentality when trying to understand how no one of the eighty existing Catechisms will meet the doctrinal viewpoint of the author of the eighty-first.

The Chinese Church is richly supplied with hymnals. It is but natural that there should be many published, for the missionaries have come from many lands and have been used to voicing their praises in the words of many writers. That which has been sung into the life of the missionary, he will naturally try to pass on in Chinese to his flock. But it must be admitted that in many cases the translated hymn has neither the force nor the beauty of the original. It has been estimated that altogether some $\mathbf{3 0 0 0}$ different hymns have been written in Chinese; probably 2000 of these will never form part of the hymns of the Chinese Church. Of the remainder, there must be at least 300 which are known in all parts of the republic because they form the nucleus of most collections. Some day there will arise a Chinese poet who will voice the aspirations, the sorrows, the confessions, the triumphs, of the Chinese Church, and then the greater part of the hymns now in use will cease to be used.

There is need for more publications on pastoral theology and homiletics. Volumes of sermons are not numerous, the best of them all being a volume issued by a Chinese pastor, P. S. Chu. It would be well if the younger generation of Chinese preachers could be furnished with more models showing them in what way the great preachers have dealt with their themes. There is no need to refer to the special literature which is being created by the 
Young Men's and Young Women's Christian Associations, the Christian Endeavour Movement and the Sunday School Union. Those great organizations know their own fields and are able to secure a circulation for their publications which the ordinary publisher may well envy. So far as the China field is concerned, there is no question that the need in these directions is very largely met. One or two other publishers are undertaking the publication of notes on the Sunday school lessons, but it is doubtful whether such ventures will have any great success.

Of the denominations, the Seventh Day Adventists are making the largest use of the press as a means of propagating their own views of truth. Their insistence on one point as more important than all others renders it out of the question for them to use much of the literature which is prepared by the Literature and Tract Societies. They have therefore established their own printing works and have at present a larger output than any other denomination. The Lutheran churches are showing very great activity, but are working in closest harmony with the existing publishing houses, either allowing these houses to be the publishers of the manuscripts which they prepare or placing their own publications on sale through these houses. This is greatly to the convenience of the missionary and Chinese purchasers. The Anglican Church has a literature committee which has produced several valuable books and also has a small, but effective, press at Ningpo. Several of the best commentaries in Chinese are issued from this press. The Presbyterian and Methodist publishing houses are serving all the churches and not limiting their work to the meeting of the needs of their own denominations. It is greatly to the advantage of the Chinese Church as a whole that so little of the literary output of the missionaries and Chinese Christians is issued from denominational presses or depots. It is also, as it seems to the writer, a healthy sign that so few of the publications mentioned in the Index have what may be termed 
a denominational bias. Apart from the books and tracts prepared by the Seventh Day Adventists, there is a harmony of view-point and a loyalty to the principles of the faith underlying the volumes included in the section on 'Religion' which augurs well for that drawing together of the churches in China which all missionaries unite in desiring.

There has been a good deal of activity in preparing church histories in Chinese. From all that one can gather the need has not yet been met. The theme is not an easy one to introduce in a land where until recently there has been no study of that general historical background which is presupposed by the writer on church history. For the most part the books hitherto written have been mere compendiums of facts. One or two attempts have been made recently to write popular studies of the lives and works of the leaders of the early Church, and some extracts from the martyrologies have been issued. But in this field there is need for much careful work. The Chinese Church should be in a position to understand and appreciate the heroism of the early martyrs, for she has passed through her own baptism of blood. The annals of that Boxer year have been collected and edited by Tsai Lien-fu. The story of the revival in Manchuria has been narrated by Chen Chun-seng. And the history oi the Christian movement in China is being penned by Mr K. Y. Chen of Nanking University. This last is the more interesting because Mr Chen worked with Dr Leighton Stuart at a series of lectures on modern missions, and that survey led him to desire to deal with the work in his own land in fuller detail.

It is perhaps in some such way as this that the Chinese Christian leaders will be led to take a larger and more effective share in this work than they have done in the past. They will feel the inadequacies and the defects of the work which the foreign missionaries have done because it seemed as if they were the only persons willing to undertake it. There has probably never been a missionary so foolish as to think that he could do literary work in Chinese 
better than the Chinese. In ninety-nine cases out of a hundred the work done by the foreigner would never have been done if he had not been able to use the services of a Chinese writer effectively. But what the missionaries have done cannot but serve to guide would-be Chinese authors on lines of effective service. Few men have done more effective work than Zia Hung-lai, but as the prefaces show he based almost every one of his books on some suggestions found in an English book or magazine article. So the remarkable stories written by Chen Chun-seng, while in one sense quite original, are the result of foreign friends narrating to him in detail the main points of stories written in English; with this nucleus he has worked out stories which are Chinese in every detail. Of course this same idea is true in its reverse of the work of foreigners. The tracts written by Dr Griffith John or the books written by Dr Hampden Du Bose are in a very real sense original, but these great missionaries never hesitated to state that it was due to their long conversations with Chinese that their works took the form they have. In fact there is good ground to argue that till the Chinese Christian Church has attained a riper development the right combination for successful work would seem to be a Chinese and a foreigner, working together harmoniously on a theme in which both are interested, the Chinese having a relatively free hand in deciding the lines on which the Chinese text shall run.

One other phase of this question needs mention. During the compilation of the Index several small booklets were sent in by one society which were understood to be the work of a Chinese. But as they were being read with a view to their proper classification, the contents seemrd strangely familiar. A little thought led in each case to an interesting discovery. One was based on a tract in Mandarin written by a missionary; another was based on a short biography of a Chinese Christian prepared in Mandarin by his pastor : each of these had been rewritten in beautiful Wenli by the nominal author. A third was 
found to be one of Dr John's Wenli tracts remoulded in even better Wenli than Dr John and his writer had used. There is of course no question of plagiarism here. There is simply the outworking of a natural feeling in the mind of a Chinese scholar that useful material had been presented in a form which was less perfect than that in which he could send it forth. It may be that some of the books on which missionaries have expended time and strength will make their final and full appeal to the Chinese mind when they have been thus rewritten by a Chinese friend.

More must not be written about the many interesting and useful discoveries made as this task has been proceeded with. What has been done is only one stage of what must be done ere the Literature Survey for China is completed. The books and tracts having been collected and classified, it becomes necessary to have them valued by competent Chinese critics. This will be a heavy task, involving much organization and calling for great patience. At present no worker seems free to face the burden and the responsibility. But just as the way opened for the compilation of the Index, so in the providence of God the way will doubtless open for the continuation of the work.

George A. Crayton 